\title{
Interplay of Personal Attitudinal Constructs towards online fashion products, Consumer Decision-Making and Image Branding: The Case of Online Fashion Products in Thailand in COVID 19 Pandemic
}

\author{
WORAKAMOL WISETSRI ${ }^{1}$, CHI HAU TAN ${ }^{2}$, BAYAR GARDI ${ }^{3}$, KANNAPAT KANKAEW ${ }^{4}$, \\ HARSANDALDEEP KAUR ${ }^{5}$, JUPETH PENTANG ${ }^{6}$ \\ ${ }^{1}$ Department of Manufacturing and Service Industry Management, KING MONGKUT'S UNIVERSITY OF \\ TECHNOLOGY NORTH BANGKOK, Bangkok, THAILAND, E-mail: worakamol.w@arts.kmutnb.ac.th \\ ${ }^{2}$ Department of Marketing, Faculty of Business and Finance, UNIVERSITI TUNKU ABDUL RAHMAN, MALAYSIA. \\ E-mail: tanchih@utar.edu.my \\ ${ }^{3}$ Department of Accounting, College of Administrative and Financial Science, KNOWLEDGE UNIVERSITY, ERBIL, IRAQ. \\ ${ }^{4}$ College of Hospitality Industry Management, SUAN SUNANDHA RAJABHAT UNIVERSITY, THAILAND. \\ E-mail: kunnapat.ka@ssru.ac.th \\ ${ }^{5}$ University School of Financial Studies, GURU NANAK DEV UNIVERSITY, Punjab, INDIA. \\ Email: harsandal.usfs@gndu.ac.in \\ ${ }^{6}$ WESTERN PHILIPPINES UNIVERSITY, PHILIPPINES.
}

\begin{abstract}
When it comes to online fashion, this research focused on the interaction between three factors: preferences for online fashion goods, consumer buying choices for online fashion products, and brand image. A descriptive correlational approach was used. A total of 184 sampled active online purchasers of fashion items from a population of 350 online buyers in Thailand participated in the research. The study was carried out with the use of tools that had been adopted. Descriptive data showed that respondents had a high preference for online marketing, a positive attitude towards online fashion goods, a high degree of consumer buying choices towards online fashion products, and a high preference for favorable brand image in the research. There were significant variations in respondents' preferences for online shopping as well as attitudes toward fashion items and consumer purchase decisions based on age, civil status, education, monthly income, and profession, according to the results of a test of difference. A further connection test revealed that respondents' liking for online marketing tends to improve their attitude toward online fashion items and consumer buying choices. In the end, the results of multiple regression analysis revealed that age, civil status and education level, online marketing approach, attitude towards online fashion goods, and brand image and attitude are all predictors of buying choices. The study's practical consequences for an internet business are addressed. The study's practical consequences for an internet business are addressed.
\end{abstract}

Keywords: Cultural dimensions; Online buying; Online Fashion Products; Purchasing decisions; Attitude.

JEL Classification: D70, M10, M20

Received: June 30, 2021

Accepted: September 30, 2021 


\title{
Interacción de los Constructos Actitudinales Personales hacia los Productos de Moda Online, la Toma de Decisiones del Consumidor y la Imagen de Marca: El Caso de los Productos de Moda en Línea en Tailandia en COVID 19 Pandemia
}

\author{
WORAKAMOL WISETSRI ${ }^{1}$, CHI HAU TAN ${ }^{2}$, BAYAR GARDI ${ }^{3}$, KANNAPAT KANKAEW ${ }^{4}$, \\ HARSANDALDEEP KAUR ${ }^{5}$, JUPETH PENTANG ${ }^{6}$ \\ ${ }^{1}$ Department of Manufacturing and Service Industry Management, KING MONGKUT'S UNIVERSITY OF \\ TECHNOLOGY NORTH BANGKOK, Bangkok, THAILAND, E-mail: worakamol.w@arts.kmutnb.ac.th \\ ${ }^{2}$ Department of Marketing, Faculty of Business and Finance, UNIVERSITI TUNKU ABDUL RAHMAN, MALAYSIA. \\ E-mail: tanchih@utar.edu.my \\ ${ }^{3}$ Department of Accounting, College of Administrative and Financial Science, KNOWLEDGE UNIVERSITY, ERBIL, IRAQ. \\ ${ }^{4}$ College of Hospitality Industry Management, SUAN SUNANDHA RAJABHAT UNIVERSITY, THAILAND. \\ E-mail: kunnapat.ka@ssru.ac.th \\ ${ }^{5}$ University School of Financial Studies, GURU NANAK DEV UNIVERSITY, Punjab, INDIA. \\ Email: harsandal.usfs@gndu.ac.in \\ ${ }^{6}$ WESTERN PHILIPPINES UNIVERSITY, PHILIPPINES.
}

\begin{abstract}
RESUMEN
En lo que respecta a la moda online, esta investigación se centró en la interacción entre tres factores: las preferencias por los productos de moda online, las elecciones de compra de los consumidores de productos de moda online y la imagen de marca. Se utilizó un enfoque descriptivo correlacional. Participaron en la investigación 184 compradores activos de artículos de moda en línea de una población de 350 compradores en línea de Tailandia. El estudio se llevó a cabo con el uso de las herramientas adoptadas. Los datos descriptivos mostraron que los encuestados tenían una alta preferencia por el marketing online, una actitud positiva hacia los artículos de moda online, un alto grado de elección de compra hacia los productos de moda online y una alta preferencia por la imagen de marca favorable en la investigación. Hubo variaciones significativas en las preferencias de los encuestados por la compra en línea, así como en las actitudes hacia los artículos de moda y las decisiones de compra de los consumidores en función de la edad, el estado civil, la educación, los ingresos mensuales y la profesión, según los resultados de una prueba de diferencias. Otra prueba de conexión reveló que el gusto de los encuestados por el marketing online tiende a mejorar su actitud hacia los artículos de moda online y las decisiones de compra de los consumidores. Por último, los resultados del análisis de regresión múltiple revelaron que la edad, el estado civil y el nivel educativo, el enfoque del marketing online, la actitud hacia los artículos de moda online y la imagen y la actitud de la marca son predictores de las elecciones de compra. Se abordan las consecuencias prácticas del estudio para un negocio en Internet. El estudio aborda las consecuencias prácticas para un negocio en Internet.
\end{abstract}

Palabras clave: Dimensiones culturales; Compra online; Productos de moda online; Decisiones de compra; Actitud.

Clasificación JEL: D70, M10, M20

Recibido: 30 de Junio de 2021

Aceptado: 30 de Septiembre de 2021 


\section{Introduction}

Customers make choices on a daily basis. These people act in accordance with the buying procedure. The goods a person buys are influenced by his or her personality and style. Before purchasing goods and services, consumers consider factors such as the product's quality, the brand, the location, and the ease of purchasing. In today's market, customers choose to shop online because of its many advantages, including ease (Akram et al., 2018). It's now commonplace for individuals to shop online since it allows them to reach a large number of people and get all the information, they need about a product at a time that suits them. People began to prefer internet shopping over the conventional method of shopping in malls and shops.

Asia's projected e-commerce value hit $\$ 540$ billion in 2015, according to Kunz (2013). By the end of 2020, it is predicted that Asia's e-commerce value will be more than the combined value of the US. This emerging market is one of the most appealing for international trade (Filieri et al., 2017). As a result of its fast expansion, individuals are forced to interact with internet technology on a regular basis. In recent years, Thailand has emerged as one of the world's leading internet marketplaces (Clemens, Gan, \& Zhang, 2014; Fu et al., 2020; Li, 2020; Zhang, 2011). There's a need to understand how customers adapt to online shopping for fashion goods as they evolve with technology and various digital media.

Consumers may purchase products and services via the internet using a web browser (Prashar, Sai Vijay, \& Parsad, 2017; Huseynov \& Yldrm, 2016; Zheng et al. 2020) through electronic commerce. Because of the growth of internet commerce, Thais have become more used to buying trendy goods, which have become a part of their quality of living (Bu et al., 2019; Hao et al., 2019). Fashion goods are increasingly being offered via internet shopping channels (Deloitte, 2015). Fashion marketing is also successful on social media, encouraging greater customer purchasing behavior, according to studies (Jin \& Ryu, 2019; Meng \& Ma, 2019; Mitterfellner, 2019; Samala \& Singh, 2019; Wang et al., 2019). As a result, internet use has a profound impact on customers' willingness to participate in online fashion marketing.

Consumer buying choices are influenced by brand image, according to research, even for trendy goods such as cell phones and other electronic devices as well as athletics or cosmetics and clothing (Alnawas \& Altarifi, 2016; Aspan et al., 2017; Chen-Yu, Cho\& Kincade, 2016; Djatmiko \& Pradana, 2016; Nawi et al., 2019; Rajagopal, 2020; Widyastuti \& Said, 2017). The image of a brand refers to the consumer's positive opinion of its quality and characteristics. In general, the more someone likes a brand, the more inclined they are to buy it. When it comes to purchasing choices and intents, brand image has a favorable correlation. As a result, customers are more inclined to acquire a product whose brand is more visible. These findings suggest that online fashion product branding has an impact on a consumer's buying choice.

Online fashion goods in Thailand have a favorable connection between online marketing features of products and customers' buying choices. However, despite many studies, more research is needed to determine this relationship. As a consequence of this research, we aim to arrive at more solid conclusions about the factors being examined. According to research, both developed and developing nations do not have a complete grasp on online consumer buying behavior and the variables that influence such behavior (Kushwaha \& Kaushal, 2020; Lee et al., 2009; Mutum \& Ghazali, 2006; Pandey \& Chawla, 2014; Swinyard \& Smith, 2003). Also, the plethora of studies showed a positive relationship between consumer purchasing decision and brand image on food and services (Breitenbach, Rodrigues, \& Brandão, 2018; Dirsehan \& Kurtuluş, 2018; Hien et al., 2020; Japutra, Ekinci, \& Simkin, 2019; Ryan \& Casidy, 2018; Sehar, Ashraf, \& Azam, 2019; Sharma, Ahuja, \& Alavi, 2020; Upadhyay, 2019) but showed limited published studies relating to online fashion products.

A final set of findings emerged from research conducted in Thailand, which included: (2) Limited empirical research into the influence of select demographic characteristics on the online buying behavior and brand image attitude; (3) Inconsistencies in consumer buying behavior and attitude towards online products; and (4) Inconsistencies in consumer buying behavior and attitude towards 
online products. To fill in a major vacuum in the literature, this study aims to expand research on how independent and dependent variables interrelate in the study. With this research, Thailand's ecommerce environment will be upgraded by gaining a better knowledge of the connection between attitudes towards online fashion items, customer buying choices, and brand image. As a result of this research, future studies will have a better knowledge of the factors that influence customer buying choices for online fashion items. Deshalb sparked a researcher's interest in the relationship between customer personality characteristics and Thailand's demographic factors. Because of it, this research was performed.

\subsection{Research Purposes}

When it comes to online fashion, this research focused on the interaction between three factors: consumers' preferences and attitudes, their buying choices, and brand image-intended to address the following questions in detail. First, what is their preference and attitude towards online fashion products? Second, what is their preference and attitude towards the brand image? In terms of sampling characteristics, is there a substantial difference between the Preference and Attitude towards Online Fashion Products, Consumer Purchasing Decision Styles, and Brand Image and Attitude? Do Preference and Attitude towards Online Fashion Products have a major impact on Consumer Purchasing Behavior and Brand Image/Attitude? Fourth, what are the factors that influence customer buying choices when it comes to Thai online fashion products?

\subsection{Research Hypotheses}

The following are the hypotheses of the study: (1) The preference and attitude towards online fashion products, consumer decision making, and brand image attitude spell significant differences to the respondents' sampling characteristics (gender, age, marital status, level of education, and occupation); (2) The preference and attitude towards online fashion products positively relates to the consumer decision making, and brand image attitude; (3) Sampling characteristics, importance and attitude towards online fashion products and brand image attitude predict consumer decision making on Thailand online fashion products.

\section{Methodology}

\subsection{Research Design and Sampling Technique}

The study is a descriptive survey correlational research to ascertain the relationship between consumer decision-making styles and their purchasing decision to Thailand's online fashion products. This design systematically and adequately describes the relationship between the selected variables of the study. The participants of the study were a total of 184 sampled active online buyers of fashion products taken from the population of 350 online buyers in Thailand. The number of samples was calculated using a free online sampling calculator Raosoft available in the link http://www.raosoft.com/samplesize.html. The sampling calculator was set at the $5 \%$ margin of error, with a $95 \%$ level of confidence and $50 \%$ distribution rate. The participants of the study were a total of 184 sampled active online buyers of fashion products taken from a population of 350 online buyers in Thailand. The number of samples was calculated using a free online sampling calculator Raosoft available in the link http://www.raosoft.com/samplesize.html. The sampling calculator was set at the $5 \%$ margin of error, with a $95 \%$ confidence level and a $50 \%$ distribution rate. The systematic nonrandom probability sampling technique was used. The respondents' complete list was requested from the participating universities' university registrars, with the three as the select random start number.

\subsection{Research Ethics Protocols}

A number of ethical concerns drove our investigation. First, the university's ethics committee authorized the survey's data protection and informed consent forms. Second, before administering 
the instruments, the researcher was briefed about the study's objectives. It was also important not to disclose any names in order to maintain confidentiality. All personal information and data provided by the participants were handled with strict confidentiality. In order to identify and choose participants, a formal request was made to the school and accepted. The researcher also obtained the permission of the parents. As part of the research, they were told of the study's goals, and their participation was guaranteed as voluntary. The study's dangers and advantages were explained to the parents, as well as the possible effects on their children. The parents permitted their children to participate in the survey with the approval of the school principal and department head. The respondents and their parents were also asked to sign a data privacy agreement form before participating in the study. Finally, respondents and institutions were kept anonymous for ethical reasons.

\subsection{Research Tool}

The research tool by Clemes, Gan, and Zhang (2014), was used to assess the preference and attitude towards online fashion items. On a five-point Likert scale, 36 questions were asked. Perceived dangers, service quality, convenience, product diversity, and customer resources were among the variables considered. Studies in the past have made use of the instrument (Lee et al., 2011; Zhang et al., 2018; Zhang, 2011). The Consumer Style Inventory (CSI) of Sprotles and Kendall (1987) was also used to measure consumer purchasing decision-making style. The CSI classifies buyer decision-making styles into eight categories: perfectionism/quality consciousness, price and value consciousness, confusion due to over choice, impulsiveness and carelessness, brand consciousness, novelty-fashion consciousness, recreational consciousness, and brand-loyalty orientation. We were asked to respond to 36 questions on a Likert scale of 1 to 5 . Researchers have utilized CSI to profile the decision-making patterns of Thai consumers on organic food items (Chen \& Lobo, 2012), luxury fashion, and homegrown brands (He \& Wang, 2015; Zhang \& Kim, 2013), and on safety foods (Zhang \& Kim, 2013). (Grunert et al., 2010; Liu, Pieniak, \& Verbeke, 2013). As a result, its application in the Thai context is of paramount significance. On-line fashion items were the focus of the current study's use of CSI. This research was based on a prior study by $L i, L i$, and Kambele that measured brand image and attitude (2012). According to research by Kim and colleagues, the brand's image and attitude were initially derived from the study's findings (2010). Five-point Likert scales were used to answer questions on fashion lifestyle personality, knowledge, brand prestige, and practicality as well as social/emotional and practical as well as financial values. Before, the instrument's applicability in the Thai setting has been examined (Hung et al., 2011; Wang, Sun \& Song, 2011; Zhang \& Kim, 2013). It was determined that the instruments were legitimate in terms of their substance. They were requested to assess the measures for their application, representation, and appropriateness of the dimensions being investigated in the research by a panel of three marketing professionals.

\subsection{Procedure and Data Analysis}

This study lasted for five months. One month was spent testing the research tool, getting survey permission, and planning data collection. Two months of data collecting took place utilizing an online survey via Google Forms, which may be accessed at https://www.google.com/forms?about=. Google Forms was used to upload the study instruments and consent forms to the server. In order to gain the consent of the responders, an invitation was issued through WhatsApp, Facebook Messenger, and personal email. The third month was dedicated to tabulation, data cleansing, and statistical analysis. This month's focus was on data analysis and interpretation. When it came time to write the report, it was time to deliver study results to appropriate authorities, format articles, and submit them to journals for research article publication.

Scoring and interpretation of the gathered data, descriptive statistics such as frequency, mean, and standard deviation were used. The computed weighted means were all analyzed and interpreted using the following scale was adopted: Strongly Agree/ Very High a (4.20-5.00); Agree/ High b (3.40-4.19); Undecided/ Moderate c (2.60-3.39); Disagree/ Low d (1.80-2.59); strongly Disagree/ Very Low e (1.001.79). Similarly, inferential statistics such as independent sample t-test, F-test of ANOVA, Pearson $r$ 
were used to test the study's hypotheses. However, F-test's result cannot find where the significant differences lie. The Post Hoc Tukey HSD was used. Finally, multiple regression was used to identify the predictors of consumer decision-making on online fashion products.

\section{Results and Discussion}

Research Question 1. What is the respondents' level of preference and attitude towards online fashion products, consumer purchasing decision, and brand image preference and attitude?

Table 1 reports that the respondents consistently rated themselves to have a high level of preference to online marketing $(M=3.67, S D=0.67)$, a highly favorable attitude towards online fashion products $(M=4.19, S D=0.56)$, high level of consumer purchasing decision towards online fashion products $(M=3.78, S D=0.38)$, and favorable brand image preference and attitude $(M=4.15, S D=0.67)$.

Table 1 Preference and attitude towards online Fashion Products, Consumer Purchasing Decision, and Brand Image and Attitude

\begin{tabular}{|c|c|c|c|}
\hline Variables & Mean & SD & Decision \\
\hline $\begin{array}{l}\text { Preference and attitude towards online Fashion } \\
\text { Products }\end{array}$ & 3.67 & 0.67 & High \\
\hline $\begin{array}{l}\text { Consumer Purchasing Decision towards online } \\
\text { fashion products }\end{array}$ & 4.19 & 0.56 & High \\
\hline Brand Image and Attitude & 4.15 & 0.67 & High \\
\hline
\end{tabular}

The highest mean of brand image and attitude of the Thai respondents showed that they have a favorable attitude and high consciousness on the brand and quality of online fashion products they purchase. It implies that they tend to patronize fashion products they trust with brand and quality. Brand image is defined as the consumers' perception and belief regarding the quality and importance of the product (Boronczyk \& Breuer, 2019; Dirsehan \& Kurtuluş, 2018; Keller, 1993; Kim, Choe, \& Petrick, 2018; Nyadzayo \& Khajehzadeh, 2016). Studies reported that brand image had been found to have a causal relationship to brand loyalty and purchasing behavior of consumers (Blackston, 2018; Dalman \& Puranam, 2017; Khan et al., 2015; Nimmermann, 2020; Shieh \& Lai, 2017; Yao, Chen, \& Xu, 2015). This finding of the study sheds light on how the Thai respondents consider the brand image as a factor in choosing online fashion products. Interestingly, the Thai respondents also assessed themselves to have a high attitude towards online fashion products and high consumer purchasing decisions. This implies that they positively manifest fashion involvement and purchasing intention. It is seen that fashion is embedded as part of their values, interest, and daily needs. In such findings, they tend to be knowledgeable about the latest fashion, styles, and trends found in social media, which makes their high level of participation in online fashion products. According to Zhang \& Zhao (2019), luxury and fashion items have a significant impact on consumers' purchasing intentions, which is inseparable from their economic well-being. Li, Zhang, \& Sun (2015) further affirmed that culture puts values on face, materialism, and pragmatism in terms of luxury and fashion consumption. They are considering that Thailand is one of the most influential markets of the world on e-commerce where rapidly growing consumer group grows, provided them flexibility and convince on online shopping and marketing (Chi, 2018; Filieri, Chen, \& Lal Dey, 2017; Filieri et al., 2019). Studies have shown that online marketing influences consumptions of fashion products such as shoes, clothes, cosmetics, pieces of jewellery, watches, apparel, traditional and modern costumes, accessories, textile, street wares, vintage materials, and the like among different countries of the world (Bhatia, 2018; Choi et al., 2016; Escobar-Rodríguez \& Bonsón-Fernández, 2017; Hagan, 2020; Kim, Kang, \& Lee, 2018; Ladhari, Gonthier, \& Lajante, 2019; Saleem \& Ellahi, 2017).

The respondents' high level of preference for online marketing manifests that they put importance on social media marketing efforts of products. For them, the online presence of products and services provides immense benefits such as easier access, more efficiency and convenience, low operational cost, and 24/7 marketing. It allowed having instant service transactions that made it more convenient 
to purchase products and services. This finding revealed that most Thai consumers have a preference for online marketing. E-commerce has been found to have a vital role in the economic development model of Thailand due to its ubiquity and convenience (Yin, Wang, \& Yang, 2016; Zhu \& Chen, 2016). For Thai online fashion, retail is influenced by demographics, motivation, and spending of consumers (Parker \& Wenyu, 2019). Studies further showed that using the internet is a predictor of online marketing among consumers (Godey et al., 2016; Ketelaar et al., 2016; Szopiński, 2016; Wilson, HallPhillips, \& Djamasbi, 2015). Social media use fundamentally transformed how people communicate, collaborate, consume, and create products (Dellarocas \& Godes). Many companies and business firms are seeking business opportunities using social media platforms because of their advantages and benefits (Paniagua \& Sapena, 2014).

Research Question 2. Is there a significant difference between the Preference and Attitude towards online Fashion Products, Consumer Purchasing Decision Styles, and Brand Image and Attitude when grouped according to Sampling Characteristics?

As seen in Table 2, the test of differences relating to the study's selected variables showed significant differences when grouped according to age, civil status, level of education, monthly income, and occupation as respondents' sampling characteristics. It suggests that the null hypothesis of the study is rejected. The significant differences are seen in preference and attitude towards online fashion products when grouped into age $\left(p=0.034^{* *}\right)$, marital status $\left(p=0.049^{*}\right)$, level of education $\left(p=0.01^{* *}\right)$, and occupation $\left(\mathrm{p}=0.003^{* *}\right)$. Implying that those in younger age brackets, single, have a higher education level, and those in white-collar jobs put high preference to online fashion products. Moreover, the only variable that defines the difference in the respondents' consumer purchasing decision is age $\left(p=0.027^{*}\right)$, were a younger group of respondents tend to manifest a higher level of consumer purchase than those in the older groups. Finally, as to brand image and brand attitude, age $\left(p=0.002^{*}\right)$, civil status $\left(p=0.02^{* *}\right)$, monthly income $\left(0.002^{* *}\right)$, and occupation $\left(p=0.045^{*}\right)$ defined differences where older respondents, those who are single, and those who have a high level of monthly income and in working as company owner and in white-collar jobs tend to manifest high preference to brand image and brand attitude of online fashion products.

Table 2 Test of Difference between the Preference and Attitude towards online Fashion Products, Consumer Purchasing Decision, and Brand Image and Attitude when grouped according to Sampling Characteristics

\begin{tabular}{llcc}
\hline Variables & $\begin{array}{l}\text { Preference and } \\
\text { attitude towards } \\
\text { online Fashion } \\
\text { Products }\end{array}$ & $\begin{array}{l}\text { Consumer } \\
\text { Purchasing }\end{array}$ & $\begin{array}{l}\text { Attitude towards } \\
\text { Brand Image }\end{array}$ \\
\hline Age & $\mathbf{0 . 0 0 4 ^ { * }}$ & $\mathbf{0 . 0 . 0 2 7} 7^{*}$ & $\mathbf{0 . 0 0 2}{ }^{* *}$ \\
Gender & $0.567 \mathrm{~ns}$ & $0.890 \mathrm{~ns}$ & $0.986 \mathrm{~ns}$ \\
Civil Status & $\mathbf{0 . 0 3 4}{ }^{*}$ & $0.876 \mathrm{~ns}$ & $\mathbf{0 . 0 0 2}{ }^{* *}$ \\
Level of Education & $\mathbf{0 . 0 0 1}{ }^{* *}$ & $0.765 \mathrm{~ns}$ & $0.986 \mathrm{~ns}$ \\
Monthly Income & $0.678 \mathrm{~ns}$ & $0.324 \mathrm{~ns}$ & $\mathbf{0 . 0 0 1}{ }^{* *}$ \\
Occupation & $\mathbf{0 . 0 0 3}{ }^{* *}$ & $0.567 \mathrm{~ns}$ & $\mathbf{0 . 0 4 5}{ }^{*}$ \\
\hline Note: ${ }^{*} \mathrm{p}<0.05 ;{ }^{* *} \mathrm{p}<0.01 ;{ }^{* * *} \mathrm{p}<0.00$ & & &
\end{tabular}

In the present study, implications showed that the younger group, more educated, and have higher monthly income tend to prefer online fashion products, consumer purchasing, and attitude towards the brand image. Hence, these respondents manifest higher enjoyment in having more time on the internet. This finding of the present study shows consistency with previous studies espousing that age, income, and education are correlated to online buying and purchasing behavior (Chen, Huang, \& Davison, 2017; Close, \& Kukar-Kinney, 2010; Constantinides, 2004; Duroy, Gorse, \& Lejoyeux, 2014; Lee, Cheng, \& Shih, 2017; Panzone, Hilton, Sale, \& Cohen, 2016; Wang, \& Somogyi, 2020; Zhu et al., 2019). In general, studies showed that sampling characteristics of consumers are factors that define the frequency of online buying and customer purchasing (Chang \& Samuel, 2004; Komodromos, Papaioannou, \& Adamu, 2018; Mortimer et al., 2016; Sin \& Tse, 2002; Xu, 2020). In the context of 
fashion lifestyle studies, it was confirmed that demographic factors influence online buying behavior and purchasing decisions (Kim \& Ko, 2012; Lian \& Yen, 2014; Shen et al., 2014). Further, this finding strengthens the report of Atchariyachanvanich and Okada (2006) thirteen years ago that Thai online consumers are relatively young, the majority working in white-collar and blue-collar jobs. Nevertheless, the study found no difference when grouped according to gender, which contradicts the findings of previous studies that females tend to use online shopping than males (Fu, 2009; Gong, Stump, \& Maddox, 2013; Rahman et al., 2018; Shen, Zhou, \& Lin, 2014; Zhang et al., 2018; Zhuang, Liu, \& Sun, 2018).

Research Question 3. Is there a significant relationship between Preference and Attitude towards online Fashion Products, Consumer Purchasing Decision, and Brand Image and Attitude?

According to Table 3, the factors in this research were tested to see whether there was a connection between them. Researchers discovered that customer buying decisions are influenced by their attitude about online fashion items, as well as their brand image. The study's null hypothesis is invalidated. To conclude, respondents' preference for fashion items purchased on the internet has a favorable correlation with their consumer buying choice and brand image attitude. According to the research results, online fashion purchases have a favorable impact on consumers' brand image and attitude toward online shopping. It offers useful references to improve social media marketing company possibilities. To put it simply, the greater respondents' consumer buying decision tends to improve their attitude and liking for online fashion goods. As a result, Thai respondents' attitudes about buying online fashion items are influenced by their online preferences. Consumers' attitudes and preferences for online fashion goods are influenced by the positive connection between consumer buying decisions. On-line shopping preference is linked with customer purchase decisions, according to prior research (Chan, Cheung, \& Lee, 2017; Nguyen, de Leeuw, \& Dullaert, 2018; Wang et al., 2016). A brand's image affects the way people feel about online fashion goods. Essentially, it implies that consumers' buying decisions are influenced by a product's brand image. Research by Choi, Ko, and Kim (2016) found that luxury-fashion brand was a significant predictor of customer buying decisions. Much additional research has shown that the brand image of food and non-food items has a direct impact on customer buying decisions (Choi Ko Kim 2016; Errajaa Daucé \& Legoherel 2020; Japutra Ekinci \& Simkin 2019; Lim Kim Cheong 2016; Liu et al. 2017; Song Wang Han 2019).

Table 3 Result of the Test of Relationship

\begin{tabular}{ccc}
\hline & $\begin{array}{l}\text { Attitude and preference } \\
\text { towards online Fashion } \\
\text { Products }\end{array}$ & Brand Image \\
\hline Consumer Purchasing Decision & $\mathrm{r}=. \mathbf{3 5 6 7}$ & $\mathrm{r}=\mathbf{2 7 6 4}$ \\
& $\mathrm{p}=. \mathbf{0 0 1} 1^{* *}$ & $\mathrm{p}=. \mathbf{0 0 2 ^ { * * }}$ \\
\hline Note: ${ }^{*} \mathrm{p}<0.05 ;{ }^{* *} \mathrm{p}<0.01 ;{ }^{* * *} \mathrm{p}<0.00$ & $\mathrm{r}=$ Pearson $\mathrm{r}$ & \\
$\mathrm{ns}=$ not significant & $\mathrm{p}=\mathrm{p}$ value &
\end{tabular}

Research Question 4. What are the predictors of consumer purchasing decisions towards online Fashion products?

Results of the multiple regression showed that the predictors of purchasing decisions to online fashion products are age, marital status, level of education, attitude towards online fashion products, and brand image. It means to say that these independent variables are significantly predicting the high level of respondents' consumer purchasing decisions towards online fashion products. The table also revealed that the adjusted R2 of 0.5520 , when converted into a percentage, is 55.20 percent, which suggests that the variance in consumer purchasing decisions of the Thai respondents is attributed to the five independent variables explored in this study. 
Table 4 Predictors of Consumer Purchasing Decision towards Online Products

\begin{tabular}{|c|c|c|c|c|c|c|}
\hline $\begin{array}{l}\text { Independent } \\
\text { Variables }\end{array}$ & $\beta^{*}$ & $\begin{array}{l}\text { Un Std. } \\
\text { Error of } \beta\end{array}$ & $\beta$ & $\begin{array}{c}\text { Std. Err. } \\
\beta\end{array}$ & $\begin{array}{c}t \\
(371)\end{array}$ & $p$ value \\
\hline Sex & 0.045 & 0.879 & 0.045 & 0.412 & 0.345 & $0.98 \mathrm{~ns}$ \\
\hline Age & 0.456 & 0.435 & 0.141 & 0.067 & 2.123 & 0.089 * \\
\hline Civil status of & 0.567 & 0.564 & 0.145 & 0.093 & 4.878 & 0.001 ** \\
\hline Education & 0.678 & 0.431 & 0.113 & 0.789 & 2.967 & 0.001 ** \\
\hline Monthly Income & 0.789 & 0.567 & 0.068 & 0.053 & 1.445 & $0.435 \mathrm{~ns}$ \\
\hline Occupation & 0.678 & 0.073 & 0.546 & 0.890 & 0.980 & $0.643 \mathrm{~ns}$ \\
\hline $\begin{array}{l}\quad \text { Attitude towards } \\
\text { online Fashion } \\
\text { Products }\end{array}$ & 0.768 & 0.543 & 0567 & 0.106 & 6.134 & 0.002 ** \\
\hline Brand Image & 0.546 & 0.072 & 0.678 & 0.890 & 3.657 & 0.002 ** \\
\hline
\end{tabular}

Therefore, younger professionals are more likely to buy online fashion items, according to the findings of the multiple regression analysis that revealed age and education had a significant impact on consumer purchasing choices. Earlier research has shown that younger professionals are more technologically adept than their older colleagues, according to the study. For this reason (Morgan and Birtwistle, 2009; O'Cass, 2004; Wu and colleagues, 2015), people are more likely to accept fashion items purchased online. According to a study by Ladhari Gontheir \& Lajante (2019), 25-30-year-old young professionals are the most likely to utilize mobile devices to make purchases. In the past, people utilized laptop computers for internet shopping. The majority of online fashion items are purchased by young professionals as a result. Because singles and married people have different goals and purchasing habits, marital status was a good predictor of buying behavior in this study. In the case of single respondents, it is ascribed to their desire and interest in a personal fashion, whereas married respondents are said to be able to buy for their families. To be successful in the online fashion company, they may need to provide a variety of online fashion clothing and accessories to meet the requirements of both married and single customers. According to prior research, the consumer's marital status has a significant impact on their buying behavior (Lee, Het al, 2019; Lim, Kim, \& Cheong, 2016; Rana \& Paul, 2017; Zheng et al., 2019). Consumers' online fashion purchases were also predicted by greater levels of education, profession, and monthly income. As a result of this study, the majority of online fashion buyers are professionals with a decent monthly income. Studies have shown that the purchasing behavior of individuals on clothing and other fashion products is related to their income and job status (Cruz-Cardenas, Arévalo-Chávez, \& Guadalupe, 2018; Mundel \& co., 2018; Saran, Roy, \& Sethuraman, 2016; Singh \& Kathuria 2016, Valaei and Nikhashemi, 2017, Weiner, 2017; Yoo, Divita \& Kim, 2018). Attitude towards online fashion goods and company image are other factors that influence online fashion product purchases. The relationship between brand image and value has been studied in recent years (Ahn \& Thomas 2020; Asshidin, Abidin \& Borhan 2016; Djatmiko \& Pradana 2016; Erraja, Daucé, \& Legoherel 2020; Foroudi et al. 2018, Japutra Ekinci \& Simkin 2019, Liu, Simkin, et al. 2017; Nyadzayo and Khajehzadeh 2016). However, this result indicates that customers' buying attitudes and willingness to pay are substantially influenced by product quality. In the minds of customers, fashion items that are expensive and of excellent quality imply a high level of worth and distinction. A consumer's self-image of superiority is boosted when they purchase branded fashion items. The brand name is an identification sign, according to Zhang \& Kim (2013).

\section{Conclusion}

This study purposively examined the interplay of three factors, namely preference and attitude towards online fashion products, consumer purchasing decisions towards online fashion products, and brand image. It employed descriptive correlational research. The study's descriptive component revealed that the respondents have a high level of preference for online marketing, a highly favorable 
attitude towards online fashion products, a high level of consumer purchasing decisions towards online fashion products, and a highly favorable brand image preference. Test of difference showed that age, civil status, education level, monthly income, and occupation spelled differences in the respondents' preference to online buying, attitude towards fashion products, consumer purchasing decision, and brand image attitude. Moreover, the test of relationship showed that the respondents' higher preference to online marketing tends to increase their attitude towards online fashion products and consumer purchasing decision. Finally, multiple regression showed that the predictors of purchasing decisions are age, civil status, level of education, online marketing strategy, attitude towards online fashion products, and brand image and attitude. The practical implications of the study in the context of online business are discussed.

\subsection{Managerial and Economics Implications}

For online customers, this research has implications that may help to improve service quality. To be more specific, this research aims to enhance conceptual knowledge of online company management and tactics directed by the firm's ethical operation, along with technology development and appropriate marketing choices. As a consequence of this research, companies will have a competitive edge (Schroeder, 2020; Vargas-Hernández, 2020; Walters \& Helman, 2020). It was shown that younger groups with more education and money tend to have a preference for online fashion items and a positive attitude towards the brand's identity. A high degree of technical literacy would suggest that the respondents are well-versed in technology. In this way, a higher level of service may be given. It is important for online merchants to take into account their customers' ages, marital status, and monthly income while designing their company. Ebenso ist it necessary to continually innovate online fashion goods, which may have an impact on consumer pleasure and ease. More than that, the greater the respondents' consumer buying decision, the more favorable their attitude and preference for online fashion goods and the brand image would be. There is a requirement for online companies to correctly design their web page, clearly presenting the genuine characteristics of online fashion goods, brands, and specs. As a result, customers' trust and readiness to pay will be monitored, helping to prevent online selling fraud (Hu \& Liu \& Sambamurthy, 2011). As a final note, establishing an internet company requires profiling and requirements analysis of potential consumers based on their age, social position, educational attainment, and attitudes towards online fashion goods. It may also be used to map out the business's long-term sustainability strategy in order to prevent losses and hazards. By providing consumers goods and services at reasonable rates, internet businesses will have a competitive business edge. It is also important that the Thai market, where internet companies successfully operate, be able to place a larger focus on social responsibility so that the profit-making activities would also benefit the whole community. It's hoped that this research will make a major contribution to the field of online fashion.

\subsection{Limitations and Avenue for Future Research}

Even while this study achieved its stated goals, it has many shortcomings that may be addressed in future research. As a first step, the research should be repeated with the addition of particular factors. This research relied only on a self-assessment survey to get its data, which limits the study's generalizations. The use of diverse methods is recommended to verify the current study's results. As a third point, there is a need to examine the social and environmental obligations of online fashion companies in conjunction with their operating standards.

\section{References}

1. Ahn, J., \& Thomas, T. K. (2020). The role of customers' perceived values of integrated resort brands in destination. Journal of Destination Marketing \& Management, 15, 100403.

2. Akram, U., Hui, P., Khan, M., Yan, C., \& Akram, Z. (2018). Factors affecting online impulse buying: evidence from China social commerce environment. Sustainability, 10(2), 352. 
3. Alnawas, I., \& Altarifi, S. (2016). Exploring the role of brand identification and brand love in generating higher levels of brand loyalty. Journal of Vacation Marketing, 22(2), 111-128.

4. Aral, S., Dellarocas, C., \& Godes, D. (2013). Introduction to the special issue-social media and business transformation: a framework for research. Information Systems Research, 24(1), 3-13.

5. Aspan, H., Sipayung, I. M., Muharrami, A. P., \& Ritonga, H. M. (2017). The Effect of Halal Label, Halal Awarness, Product Price, and Brand Image to the Purchasing Decision on Cosmetic Products (Case Study on Consumers of Sari Ayu Martha Tilaar in Binjai City). International Journal of Global Sustainability, 1(1), 55-66.

6. Asshidin, N. H. N., Abidin, N., \& Borhan, H. B. (2016). Perceived quality and emotional value that influence consumer's purchase intention towards American and local products. Procedia Economics and Finance, 35, 639-643.

7. Atchariyachanvanich, K., \& Okada, H. (2006). A study on factors affecting the purchasing process of online shopping: a survey in \& Japan. In Proc. of the 7th Asia Pacific Industrial Engineering and Management Systems Conference (pp. 2279-2286).

8. Bhatia, V. (2018). Examining consumers' attitude towards purchase of counterfeit fashion products. Journal of Indian Business Research, 10(2), 193-207.

9. Blackston, M. (2018). Brand Love is not enough: A Theory of Consumer Brand Relationships in Practice. Routledge.

10.Boronczyk, F., \& Breuer, C. (2019). The company you keep: Brand image transfer in concurrent event sponsorship. Journal of Business Research.

11.Breitenbach, R., Rodrigues, H., \& Brandão, J. B. (2018). Whose fault is it? Fraud scandal in the milk industry and its impact on product image and consumption-The case of Brazil. Food research international, 108, 475-481.

12.Brengman, M., Geuens, M., Weijters, B., Smith, S. M., \& Swinyard, W. R. (2005). Segmenting Internet shoppers based on their Web-usage-related lifestyle: a cross-cultural validation. Journal of Business Research, 58(1), 79-88.

13.Bu, D., Hanspal, T., Liao, Y., \& Liu, Y. (2019). Financial Literacy and Self-Control in FinTech: Evidence from a Field Experiment on Online Consumer Borrowing. Available at SSRN 3469571.

14.Chan, T. K., Cheung, C. M., \& Lee, Z. W. (2017). The state of online impulse-buying research: A literature analysis. Information \& Management, 54(2), 204-217.

15.Chang, J., \& Samuel, N. (2004). Internet shopper demographics and buying behaviour in Australia. Journal of American Academy of Business, 5(1/2), 171-176.

16.Chen, J., \& Lobo, A. (2012). Organic food products in China: determinants of consumers' purchase intentions. The International Review of Retail, Distribution and Consumer Research, 22(3), 293-314.

17.Chen, X., Huang, Q., \& Davison, R. M. (2017). The role of website quality and social capital in building buyers' loyalty. International Journal of Information Management, 37(1), 1563-1574.

18.Chen-Yu, J., Cho, S., \& Kincade, D. (2016). Brand perception and brand repurchase intent in online apparel shopping: An examination of brand experience, image congruence, brand affect, and brand trust. Journal of Global Fashion Marketing, 7(1), 30-44.

19.Chi, T. (2018). Understanding Chinese consumer adoption of apparel mobile commerce: An extended TAM approach. Journal of Retailing and Consumer Services, 44, 274-284.

20.Choi, E., Ko, E., \& Kim, A. J. (2016). Explaining and predicting purchase intentions following luxuryfashion brand value co-creation encounters. Journal of Business Research, 69(12), 5827-5832.

21.Clemes, M. D., Gan, C., \& Zhang, J. (2014). An empirical analysis of online shopping adoption in Beijing, China. Journal of Retailing and Consumer Services, 21(3), 364-375.

22.Close, A. G., \& Kukar-Kinney, M. (2010). Beyond buying: Motivations behind consumers' online shopping cart use. Journal of Business Research, 63(9-10), 986-992.

23.Constantinides, E. (2004). Influencing the online consumer's behavior: the Web experience. Internet research, 14(2), 111-126.

24.Cruz-Cárdenas, J., Arévalo-Chávez, P., \& Guadalupe, J. (2018). Consumer expenditures on clothing and footwear: a mixed methods study. Journal of Fashion Marketing and Management: An International Journal, 22(1), 99-113. 
25.Dalman, M. D., \& Puranam, K. (2017). Consumer evaluation of ingredient branding strategy. Management Research Review, 40(7), 768-782.

26.Deloitte. (2015). Global powers of luxury goods 2014: Engaging the future luxury consumer, http://www2.deloitte.com/ch/en/pages/consumer-business/articles/global-powers-of-luxury-goo ds.html.

27.Dirsehan, T., \& Kurtuluş, S. (2018). Measuring brand image using a cognitive approach: Representing brands as a network in the Turkish airline industry. Journal of Air Transport Management, 67, 85-93.

28.Djatmiko, T., \& Pradana, R. (2016). Brand image and product price; Its impact for Samsung smartphone purchasing decision. Procedia-Social and Behavioral Sciences, 219, 221-227.

29.Duroy, D., Gorse, P., \& Lejoyeux, M. (2014). Characteristics of online compulsive buying in Parisian students. Addictive behaviors 39(12), 1827-1830.

30.Errajaa, K., Daucé, B., \& Legoherel, P. (2020). Consumer reactions to olfactory congruence with brand image. Journal of Retailing and Consumer Services, 52, 101898.

31.Escobar-Rodríguez, T., \& Bonsón-Fernández, R. (2017). Analysing online purchase intention in Spain: fashion e-commerce. Information Systems and e-Business Management, 15(3), 599-622.

32.Filieri, R., \& Lin, Z. (2017). The role of aesthetic, cultural, utilitarian and branding factors in young Chinese consumers' repurchase intention of smartphone brands. Computers in Human Behavior, 67, 139-150.

33.Filieri, R., Chen, W., \& Lal Dey, B. (2017). The importance of enhancing, maintaining and saving face in smartphone repurchase intentions of Chinese early adopters: an exploratory study. Information Technology \& People, 30(3), 629-652.

34.Foroudi, P., Jin, Z., Gupta, S., Foroudi, M. M., \& Kitchen, P. J. (2018). Perceptional components of brand equity: Configuring the Symmetrical and Asymmetrical Paths to brand loyalty and brand purchase intention. Journal of Business Research, 89, 462-474.

35.Fu, H., Manogaran, G., Wu, K., Cao, M., Jiang, S., \& Yang, A. (2020). Intelligent decision-making of online shopping behavior based on internet of things. International Journal of Information Management, 50, 515-525.

36.Fu, R. (2009). Chinese Online Shopping report 2009: Apparel and Home Accessories the most popular

37.Godey, B., Manthiou, A., Pederzoli, D., Rokka, J., Aiello, G., Donvito, R., \& Singh, R. (2016). Social media marketing efforts of luxury brands: Influence on brand equity and consumer behavior. Journal of business research, 69(12), 5833-5841.

38.Gong, W., Stump, R. L., \& Maddox, L. M. (2013). Factors influencing consumers' online shopping in China. Journal of Asia Business Studies, 7(3), 214-230.

39.Grunert, K. G., Loose, S. M., Zhou, Y., \& Tinggaard, S. (2015). Extrinsic and intrinsic quality cues in Chinese consumers' purchase of pork ribs. Food Quality and Preference, 42, 37-47.

40.Hagan, D. (2020). The Effect of Blogging on Fashion Consumption. In Handbook of Research on Innovations in Technology and Marketing for the Connected Consumer (pp. 315-335). IGI Global.

41.Hao, Y., Liu, S., Jiesisibieke, Z. L., \& Xu, Y. J. (2019). What Determines University Students' Online Consumer Credit? Evidence From China. SAGE Open, 9(1), 2158244019833594.

42. He, J., \& Wang, C. L. (2015). Cultural identity and consumer ethnocentrism impacts on preference and purchase of domestic versus import brands: An empirical study in Thailand. Journal of Business Research, 68(6), 1225-1233.

43. Hien, N., Phuong, N., Tran, T., \& Thang, L. (2020). The effect of country-of-origin image on purchase intention: The mediating role of brand image and brand evaluation. Management Science Letters, 10(6), 1205-1212.

44.Hu, N., Liu, L., \& Sambamurthy, V. (2011). Fraud detection in online consumer reviews. Decision Support Systems, 50(3), 614-626.

45.Hung, K. P., Huiling Chen, A., Peng, N., Hackley, C., Amy Tiwsakul, R., \& Chou, C. L. (2011). Antecedents of luxury brand purchase intention. Journal of Product \& Brand Management, 20(6), 457-467. 
46. Huseynov, F., \& Yıldırım, S. Ö. (2016). Internet users' attitudes toward business-to-consumer online shopping: A survey. Information Development, 32(3), 452-465.

47.Japutra, A., Ekinci, Y., \& Simkin, L. (2019). Self-congruence, brand attachment and compulsive buying. Journal of Business Research, 99, 456-463.

48.Jin, S. V., \& Ryu, E. (2019). Celebrity fashion brand endorsement in Facebook viral marketing and social commerce: Interactive effects of social identification, materialism, fashion involvement, and opinion leadership. Journal of Fashion Marketing and Management: An International Journal, 23(1), 104-123.

49.Keller, K. L. (1993). Conceptualizing, measuring, and managing customer-based brand equity. Journal of marketing, 57(1), 1-22.

50.Ketelaar, P. E., Janssen, L., Vergeer, M., van Reijmersdal, E. A., Crutzen, R., \& van't Riet, J. (2016). The success of viral ads: Social and attitudinal predictors of consumer pass-on behavior on social network sites. Journal of Business Research, 69(7), 2603-2613.

51.Khan, N., Rahmani, S. H. R., Hoe, H. Y., \& Chen, T. B. (2015). Causal relationships among dimensions of consumer-based brand equity and purchase intention: Fashion industry. International Journal of Business and Management, 10(1), 172.

52.Kim, A. J., \& Ko, E. (2012). Do social media marketing activities enhance customer equity? An empirical study of luxury fashion brand. Journal of Business research, 65(10), 1480-1486.

53. Kim, J., Kang, S., \& Lee, K. H. (2018). How social capital impacts the purchase intention of sustainable fashion products. Journal of Business Research.

54.Kim, M., Kim, S., \& Lee, Y. (2010). The effect of distribution channel diversification of foreign luxury fashion brands on consumers' brand value and loyalty in the Korean market. Journal of Retailing and Consumer Services, 17(4), 286-293.

55.Kim, S. S., Choe, J. Y. J., \& Petrick, J. F. (2018). The effect of celebrity on brand awareness, perceived quality, brand image, brand loyalty, and destination attachment to a literary festival. Journal of Destination Marketing \& Management, 9, 320-329

56.Komodromos, M., Papaioannou, T., \& Adamu, M. A. (2018). Influence of online retailers' social media marketing strategies on students' perceptions towards e-shopping: a qualitative study. International Journal of Technology Enhanced Learning, 10(3), 218-234.

57.Kunz, D. (2013). Gesellschaft für internationale zusammenarbeit, state administration for industry and commerce of the people's republic of China. society of administration for industry and commerce (eds): e-commerce in China and germany-a sino-german comparative analysis.

58.Kushwaha, G. S., \& Kaushal, M. (2020). E-Satisfaction and E-Loyalty: Two Main Consequences of Online Buying Attributes. In Global Branding: Breakthroughs in Research and Practice (pp. 107-127). IGI Global

59.Ladhari, R., Gonthier, J., \& Lajante, M. (2019). Generation Y and online fashion shopping: Orientations and profiles. Journal of Retailing and Consumer Services, 48, 113-121.

60.Lee, H. J., Lim, H., Jolly, L. D., \& Lee, J. (2009). Consumer lifestyles and adoption of high-technology products: a case of South Korea. Journal of International Consumer Marketing, 21(2), 153-167.

61.Lee, H., Jang, Y., Kim, Y., Choi, H. M., \& Ham, S. (2019). Consumers' prestige-seeking behavior in premium food markets: Application of the theory of the leisure class. International Journal of Hospitality Management, 77, 260-269.

62.Lee, M. K., Shi, N., Cheung, C. M., Lim, K. H., \& Sia, C. L. (2011). Consumer's decision to shop online: The moderating role of positive informational social influence. Information \& management, 48(6), 185-191.

63.Lee, W. I., Cheng, S. Y., \& Shih, Y. T. (2017). Effects among product attributes, involvement, wordof-mouth, and purchase intention in online shopping. Asia Pacific Management Review, 22(4), 223229.

64.Li, G., Li, G., \& Kambele, Z. (2012). Luxury fashion brand consumers in China: Perceived value, fashion lifestyle, and willingness to pay. Journal of Business Research, 65(10), 1516-1522.

65.Li, J., Zhang, X. A., \& Sun, G. (2015). Effects of "face" consciousness on status consumption among Chinese consumers: Perceived social value as a mediator. Psychological reports, 116(1), 280-291. 
66.Li, X. (2020). Massive Open Online Courses in China. In The Roles of Technology and Globalization in Educational Transformation (pp. 98-109). IGI Global.

67.Lian, J. W., \& Yen, D. C. (2014). Online shopping drivers and barriers for older adults: Age and gender differences. Computers in Human Behavior, 37, 133-143.

68.Lim, C. H., Kim, K., \& Cheong, Y. (2016). Factors affecting sportswear buying behavior: A comparative analysis of luxury sportswear. Journal of Business Research, 69(12), 5793-5800.

69.Liu, C. W., Hsieh, A. Y., Lo, S. K., \& Hwang, Y. (2017). What consumers see when time is running out: Consumers' browsing behaviors on online shopping websites when under time pressure. Computers in Human Behavior, 70, 391-397.

70.Liu, M. T., Wong, I. A., Tseng, T. H., Chang, A. W. Y., \& Phau, I. (2017). Applying consumer-based brand equity in luxury hotel branding. Journal of Business Research, 81, 192-202.

71.Liu, R., Pieniak, Z., \& Verbeke, W. (2013). Consumers' attitudes and behaviour towards safe food in China: A review. Food Control, 33(1), 93-104.

72. Meng, J., \& Ma, Y. S. (2019). Examining the effectiveness of fashion marketing on social media: An experiment on influencer's reputation, post type, and online eWOM valence.

73. Mitterfellner, O. (2019). Fashion Marketing and Communication: Theory and Practice Across the Fashion Industry.

74.Morgan, L. R., \& Birtwistle, G. (2009). An investigation of young fashion consumers' disposal habits. International journal of consumer studies, 33(2), 190-198.

75.Mortimer, G., Fazal e Hasan, S., Andrews, L., \& Martin, J. (2016). Online grocery shopping: the impact of shopping frequency on perceived risk. The International Review of Retail, Distribution and Consumer Research, 26(2), 202-223.

76. Mundel, J., Huddleston, P., Behe, B., Sage, L., \& Latona, C. (2018). An eye tracking study of minimally branded products: hedonism and branding as predictors of purchase intentions. Journal of Product \& Brand Management, 27(2), 146-157.

77.Mutum, D., \& Ghazali, E. (2006). Online shoppers vs non-shoppers: a lifestyle study of Malaysian Internet users. Proceedings of Advances in Global Business Research, 166-176.

78.Nawi, N. B. C., Al Mamun, A., Nasir, N. A. M., Abdullah, A., \& Mustapha, W. N. W. (2019). Brand image and consumer satisfaction towards Islamic travel packages. Asia Pacific Journal of Innovation and Entrepreneurship.

79. Nguyen, D. H., de Leeuw, S., \& Dullaert, W. E. (2018). Consumer behaviour and order fulfilment in online retailing: a systematic review. International Journal of Management Reviews, 20(2), 255-276.

80.Nyadzayo, M. W., \& Khajehzadeh, S. (2016). The antecedents of customer loyalty: A moderated mediation model of customer relationship management quality and brand image. Journal of Retailing and Consumer Services, 30, 262-270.

81.0'Cass, A. (2004). Fashion clothing consumption: antecedents and consequences of fashion clothing involvement. European Journal of Marketing, 38(7), 869-882.

82.Pandey, S., \& Chawla, D. (2014). E-lifestyles of Indian online shoppers: A scale validation. Journal of Retailing and Consumer Services, 21(6), 1068-1074.

83.Paniagua, J., \& Sapena, J. (2014). Business performance and social media: Love or hate?. Business horizons, 57(6), 719-728.

84.Panzone, L., Hilton, D., Sale, L., \& Cohen, D. (2016). Socio-demographics, implicit attitudes, explicit attitudes, and sustainable consumption in supermarket shopping. Journal of Economic Psychology, 55, 77-95.

85.Parker, C. J., \& Wenyu, L. (2019). What influences Chinese fashion retail? Shopping motivations, demographics and spending. Journal of Fashion Marketing and Management: An International Journal.

86.Prashar, S., Sai Vijay, T., \& Parsad, C. (2017). Effects of online shopping values and website cues on purchase behaviour: A study using S-O-R framework. Vikalpa, 42(1), 1-18.

87.Rahman, O., Fung, B. C., Chen, Z., Chang, W. L., \& Gao, X. (2018). A study of apparel consumer behaviour in China and Taiwan. International Journal of Fashion Design, Technology and Education, 11(1), 22-33. 
88.Rajagopal, A. (2020). Developing Scale to Measure Perceived Brand Literacy of Consumer Products: An Empirical Experiment. In Innovation, Technology, and Market Ecosystems (pp. 307-332). Palgrave Macmillan, Cham.

89.Rana, J., \& Paul, J. (2017). Consumer behavior and purchase intention for organic food: A review and research agenda. Journal of Retailing and Consumer Services, 38, 157-165.

90.Ryan, J., \& Casidy, R. (2018). The role of brand reputation in organic food consumption: A behavioral reasoning perspective. Journal of Retailing and Consumer Services, 41, 239-247.

91.Saleem, A., \& Ellahi, A. (2017). Influence of electronic word of mouth on purchase intention of fashion products in social networking websites. Pakistan Journal of Commerce and Social Sciences (PJCSS), 11(2), 597-622.

92.Samala, N., \& Singh, S. (2019). Millennial's engagement with fashion brands. Journal of Fashion Marketing and Management: An International Journal.

93.Saran, R., Roy, S., \& Sethuraman, R. (2016). Personality and fashion consumption: a conceptual framework in the Indian context. Journal of Fashion Marketing and Management, 20(2), 157-176.

94.Schroeder, D. (2020). RI-A Drain on Company Resources or a Competitive Advantage?. In Responsible Innovation (pp. 51-69). Springer, Dordrecht.

95.Sehar, R., Ashraf, S., \& Azam, F. (2019). The Influence of Social Media's Marketing Efforts on Brand Equity and Consumer Response. IUP Journal of Marketing Management, 18(2), 30-53.

96.Sharma, R., Ahuja, V., \& Alavi, S. (2020). Developing a Research Instrument to Study the Impact of Consumer Brand Perception, Consumer Brand Relationship and Consumer Buying Behaviour on Online Apparel Shopping. In Digital and Social Media Marketing (pp. 67-81). Springer, Cham.

97.Shen, B., Zheng, J. H., Chow, P. S., \& Chow, K. Y. (2014). Perception of fashion sustainability in online community. The Journal of the textile institute, 105(9), 971-979.

98.Shen, C., Zhou, L., \& Lin, S. (2014, June). Older Adults' Online Shopping Behavior. In International Conference on Cross-Cultural Design (pp. 482-488). Springer, Cham.

99.Shieh, H. S., \& Lai, W. H. (2017). The relationships among brand experience, brand resonance and brand loyalty in experiential marketing: Evidence from smart phone in Taiwan. Journal of Economics \& Management, 28, 57-73.

100. Sin, L., \& Tse, A. (2002). Profiling internet shoppers in Hong Kong: demographic, psychographic, attitudinal and experiential factors. Journal of International Consumer Marketing, 15(1), 7-29.

101. Singh, A., \& Kathuria, L. M. (2016). Understanding drivers of branded food choice among lowincome consumers. Food quality and preference, 52, 52-61.

102. Song, H., Wang, J., \& Han, H. (2019). Effect of image, satisfaction, trust, love, and respect on loyalty formation for name-brand coffee shops. International Journal of Hospitality Management, 79, 5059.

103. Song, H., Wang, J., \& Han, H. (2019). Effect of image, satisfaction, trust, love, and respect on loyalty formation for name-brand coffee shops. International Journal of Hospitality Management, 79, 5059.

104. Sprotles, G. B., \& Kendall, E. L. (1986). A methodology for profiling consumers' decision-making styles. Journal of Consumer Affairs, 20(2), 267-279.

105. Swinyard, W. R., \& Smith, S. M. (2003). Why people (don't) shop online: A lifestyle study of the internet consumer. Psychology \& marketing, 20(7), 567-597.

106. Szopiński, T. S. (2016). Factors affecting the adoption of online banking in Poland. Journal of business research, 69(11), 4763-4768.

107. Upadhyay, V. (2019). Impacts of Brand Name on Consumer Buying Behavior-A Study of Theoretical Framework with Special Reference to Smart Phone in India. International Journal of Innovative Knowledge Concepts, 7(5), 196-199.

108. Valaei, N., \& Nikhashemi, S. R. (2017). Generation Y consumers' buying behaviour in fashion apparel industry: a moderation analysis. Journal of Fashion Marketing and Management: An International Journal, 21(4), 523-543. 
109. Vargas-Hernández, J. G. (2020). Uber's Strategy as a Competitive Business Model of Sharing Economy. In Sharing Economy and the Impact of Collaborative Consumption (pp. 97-115). IGI Global.

110. Walters, D., \& Helman, D. (2020). Working with the Convergence to Achieve Competitive Value Advantage. In Strategic Capability Response Analysis (pp. 305-337). Springer, Cham.

111. Wang, H., Liu, H., Kim, S. J., \& Kim, K. H. (2019). Sustainable fashion index model and its implication. Journal of Business Research, 99, 430-437.

112. Wang, O., \& Somogyi, S. (2020). Motives for luxury seafood consumption in first-tier cities in China. Food Quality and Preference, 79, 103780.

113. Wang, Q., Meng, L., Liu, M., Wang, Q., \& Ma, Q. (2016). How do social-based cues influence consumers' online purchase decisions? An event-related potential study. Electronic Commerce Research, 16(1), 1-26.

114. Wang, Y., Sun, S., \& Song, Y. (2011). Chinese luxury consumers: Motivation, attitude and behavior. Journal of Promotion Management, 17(3), 345-359.

115. Weiner, H. E. (2017). Wearing your Ethics: Investigating Consumer Purchase Intention of Ethically Produced Fashion Products.

116. Widyastuti, S., \& Said, M. (2017). Consumer consideration in purchase decision of SPECS sports shoes product through brand image, product design and price perception. International Journal of Supply Chain Management, 6(4), 199-207.

117. Wilson, E. V., Hall-Phillips, A., \& Djamasbi, S. (2015). Cognitive predictors of consumers' intention to comply with social marketing email appeals. Computers in Human Behavior, 52, 307-314.

118. Wu, M. S. S., Chaney, I., Chen, C. H. S., Nguyen, B., \& Melewar, T. C. (2015). Luxury fashion brands: factors influencing young female consumers' luxury fashion purchasing in Taiwan. Qualitative Market Research: An International Journal, 18(3), 298-319.

119. Xu, X. (2020). Examining an asymmetric effect between online customer reviews emphasis and overall satisfaction determinants. Journal of Business Research, 106, 196-210.

120. Yao, Q., Chen, R., \& Xu, X. (2015). Consistency between consumer personality and brand personality influences brand attachment. Social Behavior and Personality: an international journal, 43(9), 1419-1427.

121. Yin, S., Wang, L., \& Yang, J. (2016). An empirical study on urban e-commerce competitiveness. International Journal of Mobile Communications, 14(4), 328-347.

122. Yoo, J. J., Divita, L., \& Kim, H. Y. (2018). Predicting consumer intention to purchase clothing products made from sustainable fabrics: Implications for the fast-fashion industry. Clothing Cultures, 5(1), 47-60.

123. Zhang, B., \& Kim, J. H. (2013). Luxury fashion consumption in China: Factors affecting attitude and purchase intent. Journal of Retailing and Consumer Services, 20(1), 68-79.

124. Zhang, B., Fu, Z., Huang, J., Wang, J., Xu, S., \& Zhang, L. (2018). Consumers' perceptions, purchase intention, and willingness to pay a premium price for safe vegetables: A case study of Beijing, China. Journal of cleaner production, 197, 1498-1507.

125. Zhang, J. (2011). An empirical analysis of online shopping adoption (Doctoral dissertation, Lincoln University).

126. Zhang, Z., Li, H., Meng, F., \& Qiao, S. (2018). Gender difference in restaurant online booking timing and the moderating effects of sell-out risk and information type. Journal of Electronic Commerce Research, 19(3), 266-279.

127. Zheng, X., Men, J., Yang, F., \& Gong, X. (2019). Understanding impulse buying in mobile commerce: An investigation into hedonic and utilitarian browsing. International Journal of Information Management, 48, 151-160.

128. Zheng, Y., Yang, X., Liu, Q., Chu, X., Huang, Q., \& Zhou, Z. (2020). Perceived stress and online compulsive buying among women: A moderated mediation model. Computers in Human Behavior, 103, 13-20.

129. Zhou, J. X., Arnold, M. J., Pereira, A., \& Yu, J. (2010). Chinese' consumer decision-making styles: A comparison between the coastal and inland regions. Journal of Business Research, 63(1), 45-51. 
130.Zhu, S., \& Chen, J. (2016). E-commerce use in urbanising China: the role of normative social influence. Behaviour \& Information Technology, 35(5), 357-367.

131. Zhu, Y., Chen, Y. P., Ayed, C., Li, B., \& Liu, Y. (2019). An on-line study about consumers' perception and purchasing behavior toward umami seasonings. Food Control, 107037.

132. Zhuang, J., Liu, A., \& Sun, C. (2018). On the reproduction of gender inequality in the premium effect of the Internet on wage: A case study based on data from the Chinese Women's Status Survey (third phase). Chinese Journal of Sociology, 4(1), 145-163. 